\title{
Long-Term Carbon Accumulation in Temperate Swamp Soils: A Case Study from Greenock Swamp, Ontario, Canada
}

\author{
Emily Dazé \\ University of Toronto \\ Eunji Byun \\ University of Toronto \\ Sarah A Finkelstein ( $\nabla$ sarah.finkelstein@utoronto.ca ) \\ University of Toronto https://orcid.org/0000-0002-8239-399X
}

\section{Research Article}

Keywords: Swamp, Forested Wetland, Peat, Long-term Carbon Accumulation, Great Lakes

Posted Date: November 29th, 2021

DOI: https://doi.org/10.21203/rs.3.rs-1044474/v1

License: () (i) This work is licensed under a Creative Commons Attribution 4.0 International License. Read Full License

Version of Record: A version of this preprint was published at Wetlands on December 3rd, 2022. See the published version at https://doi.org/10.1007/s13157022-01641-8. 


\section{Abstract}

Wetlands that develop peat are a globally significant pool of soil carbon. While some wetland types such as bogs and fens are well characterized by the consistent development of carbon-rich peat, swamps soils are more variable both in terms of their carbon densities and accretion rates. Subcategorizing swamps by forest type may be a useful way of understanding this variability. Here we provide a case study of carbon accumulation in two distinct forest stands of Greenock Swamp located in the Great Lakes - St Lawrence mixed forest region in Bruce County, Ontario, Canada: an Acer - Fraxinus (maple-ash) dominant stand (i.e., broad-leaved swamp) and a Thuja occidentalis (cedar) dominant stand (i.e., needle-leaved swamp). Organic matter and organic carbon contents were analyzed among seven Acer - Fraxinus soil cores and one Thuja occidentalis core collected from Greenock Swamp. The Acer - Fraxinus cores had peat depths ranging from $18-60 \mathrm{~cm}$ with a mean organic matter content of $54 \%$ and an organic carbon content of $34 \%$ of dry mass. The Thuja occidentalis swamp core had at least $4 \mathrm{~m}$ of almost homogeneous peat with a mean organic matter content of $89 \%$. Radiocarbon dating indicates that the Acer - Fraxinus swamp accumulates peat episodically whereas the Thuja occidentalis swamp showed continuous peat accumulation since the Middle Holocene. Overall, both broad-leaved and needle-leaved swamps have important soil carbon stocks, and are prevalent wetland types in middle latitudes. Both need to be considered to fully represent the carbon pools and potential sink of temperate wetlands.

\section{Introduction}

Research on soil carbon storage in peatlands has historically focused on boreal and sub-arctic bogs and fens (Loisel et al 2014) and tropical peat swamp forests (Page et al 2011). These wetland types are known to develop deep peat profiles that store considerable amounts of carbon. They are also sensitive to changes in temperature and hydrology, so they have been considered a priority to understand under the context of climate change. Comparatively less is known about mid-latitude wetlands such as temperate swamps. Previous regional and global scale peatland-carbon studies have omitted such wetland types altogether, due to difficulties mapping them and lack of field data to parameterize models of carbon accumulation in swamp settings (Bona et al 2020). However, the Second State of the Carbon Cycle Report (Kolka et al 2018) emphasizes the importance of swamps, estimating that temperate swamps store up to $50 \%$ of all wetland carbon in North America, despite only covering $33 \%$ of wetland area (Kolka et al 2018). Locally in Southern Ontario, Canada, swamps are estimated to store $71 \%$ of wetland carbon over $75 \%$ of wetland area with large variations in soil carbon stocks across forest types and locations(Byun et al 2018).

Our understanding of peat accumulation in mid-latitude swamps is further complicated by the fact that many of them have experienced significant human alteration. Common types of alteration in swamps include logging and the creation of drainage ditches, which lower the watertable and promote the decomposition of organic materials. Alteration may leave a swamp functionally or ecologically dissimilar from pre-disturbance conditions or even converted to an entirely different land cover type. In Southern Ontario, $18 \%$ of treed swamps and $\sim 47 \%$ of shrub swamps have been converted to new land cover types since colonial settlement (Byun et al 2018). Given the ongoing anthropogenic impacts on wetlands in populated middle latitude regions, there is a need for an improved understanding of swamp soil carbon storage to facilitate more carbon considerate land-management decisions.

Another challengerelating to research on temperate swamps is their association with diverse soil andvegetation types, and hydrological regimes that complicate classification. Swamps are described in the Canadian Wetland Classification System as wetlands with $>30 \%$ cover of tall, woody vegetation (Table 1). However, swamp as a term is not used consistently. Some Canadian provinces such as Alberta and British Colombia use "wooded or forested wetland" instead(Zoltai et al 2000).Further, the "swamp" wetland class in the Canadian Wetland Classification System includes swamp types characterized by either mineral or organic soils (Table 1). Paleoecological studies have documented temperate swamps with both entirely mineral soils as well as peat profiles exceeding $40 \mathrm{~cm}$, and occasionally exceeding several meters (Mclachlan and Brubaker 1995; Bunting and Warner 1999; Newby et al 2000; Craft et al 2008; Ott and Chimner 2016).

While soil type is not a diagnostic attribute of swamps, there are several soil types more commonly associated with swamps. Mineral swamp soils typically fall under the Gleysol order, which is defined in the Canadian System of Soil Classification (CSSC) by features caused by waterlogged reducing conditions (Soil Classification Working Group 1998). If a Gleysol has an organic surface horizon, it can be classified under the great group Humic Gleysol or Peaty Phase Gleysol. Organic swamp soils fall under the Organic soil order in the CSSC, commonly subcategorized into the great groups Humisol and Mesisol depending on the degree of organic material decomposition (Soil Classification Working Group 1998). Further, the hydrological regime impacts carbon fluxes and thus peat accumulation and soil types in swamps. For example, in a study of Beverly Swamp, Southern Ontario, strong stream-wetland connections promoted greater methane and lower carbon dioxide production than no stream connection(Davidson et al 2019).As swamps are associated with a wide range of hydrological systems such as streams, rivers, lakes and floodplains(National Wetlands Working Group 1997), lack of clear, consistent classificationsand high diversity across the wetland type has limited synthesis of field data and potential for mapping.

Functionally, the species of plant that are present in a wetland contribute to controls on soil carbon in addition to hydrology and climate (Charman 2002). Soil organic carbon is mainly derived from the plants growing in situ, therefore biochemical properties of overlying swamp vegetation will impact organic matter quality and rates of carbon accumulation. In a swamp, where the vegetation is characterized by the presence of trees, the differences between the broad- and needle-leaved types are important to understand how organic carbon accumulates in the resulting soil.Temperate broad-leaved trees produce more litter than needle-leaved trees owing to annual leaf loss. Despite having more litter, topsoil in broad-leaved forests frequently contain smaller amounts of organic carbon than in needle-leaved forests (Peng et al 2020). Most broad leaves decompose much more rapidly than needle leaves and thus inherently contribute less to long-term persistence of soil organic matter (Cornwell et al 2008), although there are exceptions (Berger and Berger 2012).

The woody plant tissues including bark, trunks and branches are important elements of organic matter inputs to soils in swamps. Labile leaves and stems decompose rapidly and become incorporated into soil organic matter as humic materials through mineral stabilization (Cotrufo et al 2015). Contrastingly, recalcitrant material such as lignin-rich wood, are incorporated into soil as structural compounds by physical transfer. For this reason, leaf and stem material 
is commonly not preserved at depth in swamp soils,whereas woody materialmay remain relatively undecomposed for much longer periods of time and consequently may be found at great depths(Gholz et al 2000; Middleton 2020). The presence of wood can also reduce decomposition of other organic materials present in soil through the leaching of polyphenols, which inhibit microbial metabolism and extracellular enzyme activities (Fenner and Freeman 2020). Uprooting of trees also influences hydrology and biotic activity at the near-surface level by creating topographically heterogenous hummock-andhollow or "pit-and-mound" structures (Kooch et al 2013). When this kind of topography is situated such that the water table never exceeds the mounds, it makes for soils in close proximity with very different surface hydrology. Soil development on a dry mound will experience much great decomposition than soil development in a regularly saturated pit. Topographic surface heterogeneity can ultimately lead to soils with a large amount of spatial variability in organic matter content within a swamp setting.

Table 1 Definitions of wetland keywords used in this study.

\begin{tabular}{|lll|}
\hline Term & Definition & Source \\
\hline Swamp & $\begin{array}{l}\text { Wetland dominated by at least } 30 \% \text { tall woody vegetation. Can have either mineral or organic } \\
\text { soil }\end{array}$ & $\begin{array}{c}\text { (National Wetlands Working Group } \\
1997 \text { ) }\end{array}$ \\
\hline Peat & Soil deposit containing at least $17 \%$ organic carbon or at least 30\% organic matter & (Soil Classification Working Group \\
Organic & Soil with at least $40 \mathrm{~cm}$ of peat & 1998) \\
soil & Soil with less than $40 \mathrm{~cm}$ of peat & (National Wetlands Working Group \\
Mineral soil & 1997) & (National Wetlands Working Group \\
\end{tabular}

Greenock Swamp is an 8,000-hectare wetland located in the Teeswater watershed of Bruce County, Ontario, Canada (Figure 1). It is one of the largest continuous-area wetlands in Southern Ontario. It is mainly occupied by deciduous maple swamp, with localized stands coniferous cedar swamp, marsh and bog. Anthropogenic impacts include a $19^{\text {th }}$ century drainage ditch and canals that were dredged to transport timber during early $20^{\text {th }}$ century logging (Saugeen Valley Conservation Authority 1979). The bedrock beneath the swamp is Silurian sandstone, dolomite and shale, and is overlain by the glacial Norfolk formation (Chapman and Putnam 1984). Most of the site is either seasonally or permanently flooded. The mean annual temperature is $6.5^{\circ} \mathrm{C}$ and the mean annual precipitation is 1100-1200 mm (Environment and Climate Change Canada 2021).In this study, we compare peat depths, carbon densities and long-term rates of apparent soil-carbon accumulation in broad- and needle-leaf swamp zones of Greenock Swamp and contribute new measurements to the sparse literature on peat accumulation in broad-leaved swamp soils.

\section{Methods}

\subsection{Field Sites and Peat Coring}

Field work at Greenock Swamp was carried out September 2019. Three sites were investigated: GS02, GS04 and GS05 (Figure 1). GS02 is in the needle-leaved forest zone of Greenock Swamp. Located Northeast of Schmidt Lake, this site is characterized by a closed canopy forest containing Cedar (Thuja occidentalis) and has hummock and hollow terrain. Diameters at breast height (DBH) for the mature cedar trees ranged from $10-20 \mathrm{~cm}$. A small number of Abies balsamea(1-2 m tall) were also present. A limited number of broad-leaved trees exist in this zone including birch (Betula alleghaniensis, DBH 15-25 cm), ash (Fraxinus spp.), and maple (Acer rubrum). Sphagnum moss, grass and ferns make up the understory. There was no standing water at the time of sampling.

Sites GS04 and GS05 are both in the broad-leaved forest zone of Greenock Swamp adjacent to Cunningham Lake (Figure 2). Both sites are dominated by silver maple (Acer saccharinum), with lesser amounts of Ulmus americana, Betula alleghaniensis, Acer rubrum and Fraxinus spp. GS04 had a moderately closed canopy with trees with DBHs ranging from 15-30 cm. GS05 had a more open canopy and trees with lower DBH (10-15 cm). Both sites had standing water ranging in depths from 5-50 cm, however GS04 showed more visual evidence of fluctuating water levels as well as a possibly anthropogenic, completely linear flow channel. GSO4 also showed more beaver activity than GS05 with the presence of several lodges and felled trees showing cut marks.

A total of nine cores were collected from GS02, GS04 and GS05 (Figure 1; Table 2). Locations for coring were chosen so as to capture localized topographic variability (hollows, pools). At site GS05 two sets of two cores were taken. Each set contained one core from a deep pool and one from a shallow hollow, separated by 1-2 meters. At site GSO4 one pool/hollow set was taken as well as one additional deep pool core. At GS02 (cedar swamp) two cores were taken 2 meters from each other in a hollow. All the coring was done in 50-cm drives using a Russian peat corer except for core GS02-19-02 which was done in 1-m drives (also with a Russian peat corer). At GS02 the top $10 \mathrm{~cm}$ was also sampled by cutting a surface monolith using a serrated knife. All cores were sampled to refusal and then stored in split PVC pipe lined with plastic wrap and foil. Cores were placed in cold storage at $6^{\circ} \mathrm{C}$.

\subsection{Peat Characterization, Bulk Density and Loss-on-Ignition}

TheGS04 and GS05 cores were cutinto contiguous 2-cm intervals. A 6.28- $\mathrm{cm}^{3}$ subsample was cut from the centre of the sample using a cylindrical sampling plug. The GS02 (cedar swamp) core was cut in half lengthwise. One half was cut into contiguous 4-cm intervals for bulk density and loss-on-ignition. A 
$4 \times 2 \times 1.5 \mathrm{~cm}$ right-angled tool was used to extract contiguous $12-\mathrm{cm}^{3}$ sub-samples. All sub-samples were then weighed and dried to constant mass at $95^{\circ} \mathrm{C}$. Bulk density was calculated by BulkD $\left(\mathrm{g} / \mathrm{cm}^{3}\right)=($ Dry weight $) /($ volume$)($ Chambers et al 2011).

For loss-on-ignition, 0.5-1.0 g of the dried sample was placed in a clean crucible of known mass. Samples were then weighed to 4 decimal places, covered then combusted in a muffle furnace at $550^{\circ} \mathrm{C}$ for 4 hours, the re-weighed for organic matter estimates (Chambers et al 2011). The samples were then placed back in the furnace at $950^{\circ} \mathrm{C}$ for 2 hours to estimate carbonate content. The remaining mass weight fraction is classified as residual. Cores were also classified by soil type using the Canadian System of Soil Classification (Soil Classification Working Group 1998).

\subsection{Radiocarbon Dating}

Wood pieces of dry mass $>20 \mathrm{mg}$ were selected from core samples for radiocarbon dating. Where no wood pieces of sufficient mass in highly humified core sections could be found, composite radiocarbon dating of combinations of smaller wood and plant fragments was done. In those cases, $1-3 \mathrm{~cm}^{3}$ of sediment was removed from the core using a ceramic spoon and mixed with $5 \%$ warm $\mathrm{KOH}$. The mixture was then sieved at $90 \mu \mathrm{m}$ and rinsed with deionized water until the filtrate was clear. The residual filtride was picked though on a stereoscope to extract wood or leaf fragments in sufficient quantity to obtain a date. Radiocarbon ages were calibrated using IntCal20 (Reimer et al 2020). Median calibrated ages were used to estimate peat accretion and long-term apparent rate of carbon accumulation in the GS05-4 and GS02 cores, assuming a linear relationship between time and peat development (Clymo et al 1998). To estimate the rate of peat vertical accretion, the depth of organic section was divided by basal age. For cores with multiple radiocarbon dates, peat accretion was calculated using weighted averages by depth interval. Apparent rates of carbon accumulation (aCAR) were calculated by multiplying carbon density $\left(\mathrm{gC} / \mathrm{cm}^{3}\right)$ by accretion rate $(\mathrm{cm} / \mathrm{yr})$ for the specified depth range.

\subsection{Carbon Elemental Analysis}

Total carbon (TC) and total inorganic carbon (TIC) content was measured by elemental analysis for cores GS04-01 and GS05-04 (Table 2). Dried samples ground to a fine powder using a Retsch MM200 Oscillating Mill, and analyzed using the SSM-5000a TOC Solid Sample Combustion unit of the Shimadzu TOC-L TOC/TN analyzer at the ANALEST facility (Department of Chemistry, University of Toronto). The instrument was calibrated with glucose and sodium carbonate standards. TCwas measured by combusting samples at $950^{\circ} \mathrm{C}$, at which temperature all carbon becomes oxidized. The resulting carbon dioxide emission is measured to determine the total mass of carbon in the sample. To measure TIC, samples were first acidified with $0.5 \mathrm{ml}$ of phosphoric acid and then heated to $200^{\circ} \mathrm{C}$. Total organic carbon (TOC) was calculated as the difference between TC and TIC; and was compared to organic matter content as determined by loss-on-ignition. TOC and LOI data from a previously collected cedar swampcoreatGreenockSwamp(Byun et al 2021) were used to convert organic matter determinations from loss-on-ignition to TOC for the cedar swamp core.

\section{Results}

\subsection{Greenock Swamp Core Characterization}

The broad-leaved swamp cores are characterized by organic accumulation confined to the upper 60 cmof the core(Table 2). The three cores from GS04 have similar peat depths, ranging from 18-22 cm. At site GS05 the organic sections are deeper but also more variable in length, ranging from $21-60 \mathrm{~cm}$. It has a crumbly to pasty texture, dark brown to black colour and is well humified but with some visible rootlets and wood pieces. The transition from peat to inorganic soil varies from abrupt to gradual. The inorganic sections are dark grey in colour and vary from sandy to silty in texture. No visible plant fragments were observed in the inorganic section of these cores. Cores taken from hollows had more organic soil accumulation than cores taken from pools across both sites. Cores GS05-02 and GS05-04 were classified using the Canadian System of Soil Classification as Organic Humisols with $>40 \mathrm{~cm}$ of humified material (Kroetsch et al 2011). The rest of the broad-leaved cores were classified as Humic Gleysols, with $<40 \mathrm{~cm}$ of highly humified material, underlain by gleyic sediments (Soil Classification Working Group 1998).

Table 2 All cores analyzed for this study. Swamp type, topography, core length and depth of organic section were all determined in the field. * GS02 refusal depth was set by a log, not by contact with underlying inorganic sediments 


\begin{tabular}{|c|c|c|c|c|c|c|c|}
\hline Core & Coordinate & $\begin{array}{l}\text { Swamp } \\
\text { type }\end{array}$ & $\begin{array}{l}\text { Dominant Tree } \\
\text { Species }\end{array}$ & $\begin{array}{l}\text { CSsc Soil } \\
\text { Order }\end{array}$ & $\begin{array}{l}\text { Topography of Sample } \\
\text { location }\end{array}$ & $\begin{array}{l}\text { Length of core } \\
\text { (cm) }\end{array}$ & $\begin{array}{l}\text { Depth of Organic } \\
\text { Section }(\mathrm{cm})\end{array}$ \\
\hline GS04-01 & $\begin{array}{l}\left(44.1559^{\circ}\right. \\
\left.-81.3894^{\circ}\right)\end{array}$ & $\begin{array}{l}\text { Broad- } \\
\text { leaved }\end{array}$ & Maple & $\begin{array}{l}\text { Humic } \\
\text { Gleysol }\end{array}$ & Hollow & 32 & 20 \\
\hline GSO4-02 & $\begin{array}{l}\left(44.1559^{\circ}\right. \\
\left.-81.3894^{\circ}\right)\end{array}$ & $\begin{array}{l}\text { Broad- } \\
\text { leaved }\end{array}$ & Maple & $\begin{array}{l}\text { Humic } \\
\text { Gleysol }\end{array}$ & Deep pool & 46 & 18 \\
\hline GSO4-03 & $\begin{array}{l}\left(44.1553^{\circ}\right. \\
\left.-81.3891^{\circ}\right)\end{array}$ & $\begin{array}{l}\text { Broad- } \\
\text { leaved }\end{array}$ & Maple & $\begin{array}{l}\text { Humic } \\
\text { Gleysol }\end{array}$ & Hollow & 50 & 22 \\
\hline GSO5-01 & $\begin{array}{l}\left(44.1520^{\circ}\right. \\
\left.-81.3885^{\circ}\right)\end{array}$ & $\begin{array}{l}\text { Broad- } \\
\text { leaved }\end{array}$ & Maple & $\begin{array}{l}\text { Humic } \\
\text { Gleysol }\end{array}$ & Pool or flow channel & 84 & 36 \\
\hline GSO5-02 & $\begin{array}{l}\left(44.1520^{\circ}\right. \\
\left.-81.3885^{\circ}\right)\end{array}$ & $\begin{array}{l}\text { Broad- } \\
\text { leaved }\end{array}$ & Maple & Humisol & Hollow & 83 & 60 \\
\hline GSO5-03 & $\begin{array}{l}\left(44.1515^{\circ}\right. \\
\left.-81.3878^{\circ}\right)\end{array}$ & $\begin{array}{l}\text { Broad- } \\
\text { leaved }\end{array}$ & Maple & $\begin{array}{l}\text { Humic } \\
\text { Gleysol }\end{array}$ & Pool & 60 & 33 \\
\hline GSO5-04 & $\begin{array}{l}\left(44.1515^{\circ}\right. \\
\left.-81.3878^{\circ}\right)\end{array}$ & $\begin{array}{l}\text { Broad- } \\
\text { leaved }\end{array}$ & Maple & Humisol & Hollow & 81 & 48 \\
\hline $\begin{array}{l}\text { GSO2- } \\
19-02\end{array}$ & $\begin{array}{l}\left(44.1730^{\circ}\right. \\
\left.-81.3080^{\circ}\right)\end{array}$ & $\begin{array}{l}\text { Needle- } \\
\text { leaved }\end{array}$ & Cedar & $\begin{array}{l}\text { Mesisol- } \\
\text { Humisol }\end{array}$ & Hollow & $400^{*}$ & $>400$ \\
\hline
\end{tabular}

The cedar swamp zone core (GS02) consists of uniform dark brown, moderately humified peat, with two sections consisting of solid undecomposed woody material (150-170 cm and 230-366 cm).Although this core was sampled to refusal, no inorganic sediment was observed at the bottom of the core; thus refusal was most likely a larger log and organic accumulation likely continues below what was captured in the peat corer. This soil is classified as an Organic Mesisol / Humisol due to thick accumulation of moderately decomposed organic material.

\subsection{Bulk Density and Loss-on-Ignition}

Bulk density and organic matter are inversely related in all the cores (Figure3, Figure 4). The three GS04 cores follow a similar trend of high ( $>50 \%$ ) organic matter until around $20 \mathrm{~cm}$ at which point organic matter drops significantly (<20\%) (Figure 4). The GS05 cores are more heterogenous, both in terms of length and distribution of organic sections. GS05-01 and GS05-02 are located <2 m apart, but have the smallest and largest peat thicknesses. The mean bulk density of the organic section of all seven cores is $0.19 \mathrm{~g} / \mathrm{cm}^{3}$ and the mean organic matter content is $54.27 \%$. GS02-19-02 shows no significant change in organic matter or bulk density. Over the entire length of the core, the mean bulk density was $0.093 \mathrm{~g} / \mathrm{cm}^{3}$ and the mean organic matter content was $89.5 \%$. The slight increase in organic matter around $160 \mathrm{~cm}$ and $260 \mathrm{~cm}$ correspond to sections of the core that were entirely filled with undecomposed wood (Figure 4).

\subsection{Radiocarbon Dating}

Table 3 Radiocarbon age estimates for Greenock Swamp samples, calibrated with OxCal v4.4 (Ramsey 2009) and the IntCal20calibration curve (Reimer et al 2020). * indicates a basal depth ( $<10 \mathrm{~cm}$ above base of the organic section)

\begin{tabular}{|c|c|c|c|c|c|c|}
\hline Lab ID & Core & $\begin{array}{l}\text { Sample Depth } \\
\text { (cm) }\end{array}$ & Dated Material & $\begin{array}{l}\text { Conventional }{ }^{14} \mathrm{C} \text { age }\left({ }^{44} \mathrm{C}\right. \\
\text { yrs BP })\end{array}$ & $\begin{array}{l}2-\sigma \\
\text { Calibrated age (yrs } \\
\text { BP) }\end{array}$ & $\begin{array}{l}\text { Median calibrated age (yrs } \\
\text { BP) }\end{array}$ \\
\hline $\begin{array}{l}\text { UOC- } \\
13851\end{array}$ & GS04-02 & $12-14^{\star}$ & Wood & $141 \pm 25$ & $120-52$ & 120 \\
\hline $\begin{array}{l}\text { UOC- } \\
13432\end{array}$ & GS05-01 & $24-26 *$ & Wood & $5410 \pm 27$ & $6288-6186$ & 6240 \\
\hline $\begin{array}{l}\text { UOC- } \\
13852\end{array}$ & GS05-02 & $55-57^{*}$ & $\begin{array}{l}\text { Wood and plant } \\
\text { material }\end{array}$ & $6326 \pm 31$ & $7316-7235$ & 7240 \\
\hline $\begin{array}{l}\text { UOC- } \\
13431\end{array}$ & GS05-04 & $22-24$ & Wood & $127 \pm 25$ & $151-9$ & 110 \\
\hline $\begin{array}{l}\text { UOC- } \\
13853\end{array}$ & GS05-04 & $38-40 *$ & $\begin{array}{l}\text { Wood and plant } \\
\text { material }\end{array}$ & $3961 \pm 26$ & $4450-4381$ & 4430 \\
\hline $\begin{array}{l}\text { UOC- } \\
13433\end{array}$ & $\begin{array}{l}\text { GSO2-19- } \\
02\end{array}$ & $165-166$ & Wood & $3071 \pm 30$ & $3366-3209$ & 3290 \\
\hline $\begin{array}{l}\text { UOC- } \\
13434\end{array}$ & $\begin{array}{l}\text { GSO2-19- } \\
02\end{array}$ & $262-266$ & Wood & $4005 \pm 25$ & $4522-4418$ & 4480 \\
\hline
\end{tabular}

The results of radiocarbon dating are reported in Table 3. The dated materials from the broad-leaved swamp cores GS05 and GS04 had a large discrepancy in ages, varying between century-old to millennia-old. The century old material was from the two shallowest depths, GS04-02 12-14 cm and GS05-04 22-24 cm. 
However, GS05-01 24-26 cm returned a Middle Holocene age of 7244 yrs BP. Core GS05-04 was sampled at two depths and returned both a century-old age and a deeper millennia-old age. GSO2 returned two Middle / Late Holocene ages.

Radiocarbon dates were used to estimate long-term apparent rates of peat vertical accretion and carbon accumulation, but these values for the broad-leaved swamp cores must be interpreted with caution as these sites are not characterized by continuous accumulation of organic matter. For GS02-19-02, accretion rates were estimated by assuming linear rates between radiocarbon dates. Apparent rates of organic carbon accumulation (aCAR)(Clymo et al 1998; Young et al 2021)were calculated using results from carbon elemental analysis (Table 4).In GS05-04, peat accretion and aCAR values differ by 1-2 orders of magnitude from depths $23 \mathrm{~cm}$ to $39 \mathrm{~cm}$, suggesting strongly non-continuous regime of peat accumulation. These aCAR values cannot be directly compared to the needleleaved core (GS02-19-02) showing accumulation rates consistent with other cedar swamp peat cores (Ott and Chimner 2016; Byun et al 2021).

Table 4 Peat accretion rate,apparent rate of carbon accumulation (aCAR) and areal carbon stock [over depth range (cm) specified]. aCAR for GS02-19-02 (0$264 \mathrm{~cm}$ ) was calculated using both accretion rates weighted by depth interval.* Indicates peat that has not accumulated continuously and thus aCAR values that cannot be directly compared to continuously accumulated peat

\begin{tabular}{|c|c|c|c|}
\hline Core & Peat accretion $(\mathrm{mm} / \mathrm{yr})$ & $\operatorname{aCAR}\left(g C^{*} m^{-2 *} \mathrm{yr}^{-1}\right)$ & Arealcarbon stock $\left(\mathrm{kg} \mathrm{C} \mathrm{m}^{-2}\right)$ [for depth range $\left.(\mathrm{cm})\right]$ \\
\hline \multirow[t]{2}{*}{ GSO4-01 } & - & - & 13.5 \\
\hline & & & [0-20] \\
\hline \multirow[t]{2}{*}{ GSO4-02 } & 0.69 & - & - \\
\hline & {$[0-13]$} & & \\
\hline \multirow[t]{2}{*}{ GSO5-01 } & 0.040 & - & - \\
\hline & [0-25] & & \\
\hline \multirow[t]{2}{*}{ GSO5-02 } & 0.077 & - & - \\
\hline & [0-56] & & \\
\hline \multirow[t]{2}{*}{ GSO5-04 } & 1.3 & $53.1^{*}$ & 36.0 \\
\hline & [0-23] & [0-23] & [0-48] \\
\hline \multirow[t]{2}{*}{ GSO5-04 } & 0.087 & $6.6^{*}$ & - \\
\hline & [0-39] & [0-39] & \\
\hline \multirow[t]{2}{*}{ GSO2-19-02 } & 0.49 & 24.1 & 60.3 \\
\hline & {$[0-165.5]$} & {$[0-165.5]$} & {$[0-120]$} \\
\hline \multirow[t]{2}{*}{ GSO2-19-02 } & 0.83 & 42.7 & - \\
\hline & {$[165.5-264]$} & {$[165.5-264]$} & \\
\hline \multirow[t]{2}{*}{ GSO2-19-02 } & 0.62 & 30.9 & - \\
\hline & {$[0-264]$} & {$[0-264]$} & \\
\hline
\end{tabular}

\subsection{Carbon Elemental Analysis}

The organic carbon results follow the same trend as the loss-on-ignition $550^{\circ} \mathrm{C}$ (Figure 5). In the organic section of GS04-01 (0-20 cm) the mean organic carbon value is $30.6 \%$. The organic section of GS05-04 $(0-48 \mathrm{~cm})$ has a mean organic carbon value of $38.9 \%$.Organic matter content estimated by $\mathrm{LOI} 550^{\circ} \mathrm{C}$ plots at roughly $50 \%$ of organic carbon estimated by the TOC analyzer for bothGS04-01 and GS05-04 as illustrated by the $0.5^{*} \mathrm{x}$ line in Figure 6 The scatter in data points around the regression line may related to the fact that LOI samples were not homogenized as was the case for the carbon elemental analysis samples.

Loss-on-ignition $950^{\circ} \mathrm{C}$ is higher overall than inorganic carbon measured on the analyzer. For the entire length of GS04-01, inorganic carbon levels were below the detection limit of the carbon analyzer. In GS05-04, inorganic carbon was only present in large enough quantity to be measured below $70 \mathrm{~cm}$, but never exceeded $10 \%$. For both cores, most of the carbon was in the form of organic carbon thus we do not consider the inorganic fraction further. Areal carbon stocks exceeded $60 \mathrm{~kg} \mathrm{C} \mathrm{m}^{-2}$ for depths $0-120 \mathrm{~cm}$ in the cedar swamp core (GS02), which exceeds mean values for wetland types included in the synthesis of Nahlik and Fennessy (2016). Areal carbon stocks are lower as expected for the broad-leaved swamp cores, and are similar to the values reported for comparable depths in estuarine woody or other forested wetland types in the United States (Nahlik and Fennessy, 2016).

\section{Discussion}

\subsection{Organic and Mineral Soil in Greenock Swamp}

Page 6/14 
The results from Greenock swamp show considerable heterogeneity in swamp soils, which can accumulate significant amounts of peat in close proximity to mineral soils. Both GS05-02 and GS05-04 have greater than $40 \%$ organic matter content for at least $40 \mathrm{~cm}$ depth (Figure 4), which makes them organic soils under the Canadian wetland classification system (National Wetlands Working Group 1997). Although GS05-01 is directly adjacent to GS05-02, it has significantly less organic material only up to $\sim 30 \mathrm{~cm}$ depth and is classified as a mineral soil. Still, apart from the surface $2 \mathrm{~cm}$, GS05-01 has organic matter content consistently above $40 \%$. This pattern of organic soil adjacent to mineral soil is repeated with GS05-03 and GS05-04. Despite being separated by only a few meters distance and sharing a similar vegetation assemblage, GS05-04 meets the definition of organic soil, whereas GS05-03 does not.

Both of the GS05 cores with organic soil were taken from hollows and both of the adjacent mineral soil cores were taken from pools. The proximity of the cores in each pair makes it unlikely that differences in vegetational input are the major factor driving the disparity in organic matter accumulation. The role of local topography and its connection to hydrology is likely influencing this difference in organic matter accumulation at these sites. At the time of sampling in mid-September, the hollows had no standing water whereas the pools had up to $50 \mathrm{~cm}$. Therefore, the soils in the pools are likely saturated with water for much longer periods, if not all the time, whereas the soils from the hollows are exposed to air for at least some period of the year, as they were at the time of sampling. Water-saturated, anaerobic conditions are preferable for minimizing organic matter decomposition in a system with no water flow. However, a system with streamflow will behave differently. Streamflow hinders the accumulation of particulate organic matter due to its erosive powers (Bernal and Mitsch 2012). In forested wetlands, streamflow can remain relatively stable throughout the year if the wetland is connected to a large aquifer (Verry 1997). If the pools at Greenock swamp were the result of natural channelization and experience streamflow throughout the year, this could explain why organic matter has not accumulated in them to the same extent it has in the hollows.

In Greenock Swamp, vegetation does help delineate between organic and mineral soils in some cases. The broad-leaved swamp cores, despite the fact that some were classified as mineral soils and others organic, in general all had less than $1 \mathrm{~m}$ organic material before transitioning to typical highly inorganic, gleyed sediments. This contrasted starkly with the needle-leaved site which had at least $4 \mathrm{~m}$ of consistently organic rich peat. Speculatively, the presence of Sphagnum moss in the needle-leaved zone of Greenock swamp suggests a more stable water table, as it is a desiccation-avoidant species (Hájek 2014). Sphagnum is characteristic of carbon-rich bog soils, which develop deep peat deposits. However, in the needle-leaf zone of Greenock Swamp, despite the presence of Sphagnum, the peat is woody in the top 4 meters, making it distinct from typical boreal/sub-arctic open bog peat.

\subsection{Episodic and Continuous Organic Matter Accumulation in Greenock Swamp}

Neither cores from the hollows nor the pools from GS05 showed evidence for stable rates of accumulation of organic matter, meaning that continuous peat age-depth models in the broad-leaved forest zone of Greenock Swamp could not be developed (Table 4). Surface flows likely prevent the stable accumulation of organic matter in the pools and channels whereas in the hollows, seasonal water table depth fluctuations promote partial oxidation of surface soil organic matter, particularly during late growing season (Trettin et al 2020).

The radiocarbon dates from GS05-04 and GS05-01 corroborate the episodic accumulation of organic matter in the broad-leaved zone. The two dated cores from this zone returned a difference in age of approximately 6000 years for a depth of $24 \mathrm{~cm}$. Such a large disparity suggests that the soils from these cores can contain very old material in close proximity to young material as a result of decomposition relating to complex hydrology involving surface flows and seasonal water table drawdown. In the few examples of broad-leaved swamps that have been dated with radiocarbon, continuous models of peat accumulation have similarly not been recorded (Watts 1979; Turton and McAndrews 2001; Momsen 2007). The needle-leaved zone of Greenock Swamp, on the other hand, appears to accumulate organic matter continuously, analogous to peat accumulation in a boreal bog or fen.

\subsection{Using Loss-on-Ignition and Elemental Analysis for Estimating Carbon}

Loss-on-ignition (LOI) is a simple, inexpensive and commonly used method for soil organic matter estimates (Heiri et al 2001). Deriving estimates of carbon content from LOI assume both the accuracy of the organic matter determinations (Santisteban et al 2004), and a conversion factors (often 50\%). The relationship between organic matter and organic carbon depends on the type of organic matter and the degree of decomposition. For this reason, it has been recommended to develop wetland type specific conversion factors (Klingenfuß et al 2014). The conversion factor calculated from the Greenock broad-leaved cores (Figure 6) $\mathrm{OC}=0.51 * \mathrm{OM}+2.3$ is similar to the 0.5 conversion factor commonly used in the literature.

\section{Conclusion}

This research investigatedlong-term carbon accumulation across two forest types in Greenock Swamp, a temperate swamp located in Bruce County, Ontario, Canada.Seven cores were collected from an Acer-Fraxinus (maple-ash) broad-leaved swamp as well as an additional single core from a Thuja occidentalis (cedar) needle-leaf swamp for comparisons across two dissimilar swamp forest types. The broad-leaved swamp cores had shorter peat depths, higher bulk densities, lower organic matter content and areal carbon stocks compared to the needle-leaved swamp core. Radiocarbon dating of these cores also suggests that soil in the broad-leaved zone accumulates peat episodically, whereas the needle-leaved zone accumulates peat more continuously. The differences between the broad- and needle-leaved zones are likely related to the hydrology, with greater streamflow and seasonal water table change leading to denser, more humified soils in the broad-leaved zone. While apparent rates of carbon accumulation cannot be easily calculated for broad-leaved swamps, the data presented here suggest that the existing carbon stocks in these systems are significant and should be considered in inventories and land-use planning. Overall North American swamps have an important amount of carbon stored in their soils, particularly in the top meter(Nahlik and Fennessy 2016). However, swamps soils are highly variable and thus subcategorizing them by swamp type will help to better understand these systems. Despite this, they are often presented as one consistent wetland type (Kolka et al 2018). This comparative analysis demonstrates differences in peat depth, organic matter, organic carbon and peat 
accretion rates between broad-leaved and needle-leaved swamp forests. Needle-leaved swamps in particular stand out for having significant peat accumulation well above $1 \mathrm{~m}$ depth.

Swamps in general would benefit from a more robust sub-classification systemthat addresses the variability within this wetland type. Current terminology is sometimes redundant (e.g. swamp, forested wetland) or vague, making comparisons between sites difficult. Additionally, most of the work done on long-term wetland carbon accumulation has been done in the context of continuously accumulating peat. This framework does not suit sites such as the broad-leaved zone of Greenock Swamp, where peat accumulates episodically because it can result in misleadingly high (or low) aCAR values.Further research is needed to address the under-representation of broad-leaved swamps and their potential for long-term carbon storage through episodic accumulation.Systematic analysis of factors such as hydrology, soil chemistry and soil temperature and their effect on carbon accumulation in broad-leaved swamps are necessary to help elucidate carbon storagein this important wetland type.

\section{Declarations}

Funding: This research was supported by grants to SAF from the Natural Sciences and Engineering Research Council (Canada).

Conflicts of interest/Competing interests: The authors declare no competing interests.

Availability of data and material: Datasets used here will be publicly available at Pangaea.deat the time of publication.

Authors' contributions: ED: Data curation, Formal analysis, Investigation, Writing - Original Draft; EB: Conceptualization, Data curation, Methodology, Writing review and editing; SAF: Conceptualization, Data curation, Funding acquisition, Supervision, Writing - review and editing.

\section{References}

1. Berger TW, Berger P (2012) Greater accumulation of litter in spruce (Picea abies) compared to beech (Fagus sylvatica) stands is not a consequence of the inherent recalcitrance of needles. Plant and Soil 358:349-369. https://doi.org/10.1007/s11104-012-1165-z

2. Bernal B, Mitsch WJ (2012) Comparing carbon sequestration in temperate freshwater wetland communities. Global Change Biology 18:1636-1647. https://doi.org/10.1111/j.1365-2486.2011.02619.x

3. Bona KA, Shaw C, Thompson DK, et al (2020) The Canadian model for peatlands (CaMP): A peatland carbon model for national greenhouse gas reporting. Ecological Modelling 431:109164. https://doi.org/10.1016/j.ecolmodel.2020.109164

4. Bunting MJ, Warner BG (1999) Late Quaternary vegetation dynamics and hydroseral development in a shrub swamp in southern Ontario, Canada. Canadian Journal of Earth Sciences 36:1603-1616. https://doi.org/10.1139/e99-068

5. Byun E, Cowling SA, Finkelstein SA (2021) Holocene regional climate change and formation of southern Ontario's largest swamp inferred from a kettlelake pollen record. Quaternary Research 1-19. https://doi.org/10.1017/qua.2021.54

6. Byun E, Finkelstein SA, Cowling SA, Badiou P (2018) Potential carbon loss associated with post-settlement wetland conversion in southern Ontario, Canada. Carbon Balance and Management 13:6. https://doi.org/10.1186/s13021-018-0094-4

7. Chambers FM, Beilman DW, Yu Z (2011) Methods for determining peat humification and for quantifying peat bulk density, organic matter and carbon content for palaeostudies of climate and peatland carbon dynamics. Mires and Peat 7:1-10.

8. Chapman LJ, Putnam DF (1984) Physiography of southern Ontario. Ontario Geological Survey, Map P.2715 (coloured). Scale 1:600 000.

9. Charman DJ (2002) Peatlands and environmental change. Wiley, New York

10. Clymo RS, Turunen J, Tolonen K (1998) Carbon Accumulation in Peatland. Oikos 81:368-388. https://doi.org/10.2307/3547057

11. Cornwell WK, Cornelissen JHC, Amatangelo K, et al (2008) Plant species traits are the predominant control on litter decomposition rates within biomes worldwide. Ecology Letters 11:1065-1071. https://doi.org/10.1111/j.1461-0248.2008.01219.x

12. Cotrufo MF, Soong JL, Horton AJ, et al (2015) Formation of soil organic matter via biochemical and physical pathways of litter mass loss. Nature Geoscience 8:776-779. https://doi.org/10.1038/ngeo2520

13. Craft C, Washburn C, Parker A (2008) Latitudinal Trends in Organic Carbon Accumulation in Temperate Freshwater Peatlands. In: Vymazal J (ed) Wastewater Treatment, Plant Dynamics and Management in Constructed and Natural Wetlands. Springer Netherlands, Dordrecht, pp 23-31

14. Davidson SJ, Strack M, Bourbonniere RA, Waddington JM (2019) Controls on soil carbon dioxide and methane fluxes from a peat swamp vary by hydrogeomorphic setting. Ecohydrology 12:8. https://doi.org/10.1002/eco.2162

15. Environment and Climate Change Canada (2021) Canadian Climate Normals 1981-2010 Station Data - Climate - Environment and Climate Change Canada. In: Chatsworth Ontario Weather Station: Canadian Climate Normals 1981-2010 Station Data.

https://climate.weather.gc.ca/climate_normals/results_1981_2010_e.html?

searchType=stnProx\&txtRadius=200\&selCity=\&selPark=\&optProxType=custom\&txtCentralLatDeg=44\&txtCentralLatMin=09\&txtCentralLatSec=23.9\&txtCe Accessed 27 May 2021

16. Fenner N, Freeman C (2020) Woody litter protects peat carbon stocks during drought. Nature Climate Change 10:363-369. https://doi.org/10.1038/s41558-020-0727-y

17. Gholz HL, Wedin DA, Smitherman SM, et al (2000) Long-term dynamics of pine and hardwood litter in contrasting environments: Toward a global model of decomposition. Global Change Biology 6:751-765. https://doi.org/10.1046/j.1365-2486.2000.00349.x 
18. Hájek T (2014) Physiological Ecology of Peatland Bryophytes. In: Hanson DT, Rice SK (eds) In: Photosynthesis in Bryophytes and Early Land Plants. Springer Netherlands, pp 233-252

19. Heiri O, Lotter AF, Lemcke G (2001) Loss on ignition as a method for estimating organic and carbonate content in sediments: Reproducibility and comparability of results. Journal of Paleolimnology 25:101-110. https://doi.org/10.1023/A:1008119611481

20. Klingenfuß C, Roßkopf N, Walter J, et al (2014) Soil organic matter to soil organic carbon ratios of peatland soil substrates. Geoderma 235-236:410417. https://doi.org/10.1016/j.geoderma.2014.07.010

21. Kolka R, Trettin C, Tang W, et al (2018) Terrestrial Wetlands. In: Cavallaro N, Shrestha G, Birdsey R, et al (eds) Second State of the Carbon Cycle Report (SOCCR2): A Sustained Assessment Report. U.S. Global Change Research Program, Washington, DC, USA, pp 507-567

22. Kooch Y, Hosseini SM, Mohammadi J, Hojjati SM (2013) Effects of Pit and Mound Landscape on Soil Ecosystem Engineers at Local Scales - a Case Study in Hyrcanian Forest. Molecular Soil Biology 4:7-15. https://doi.org/10.5376/msb.2013.04.0002

23. Kroetsch DJ, Geng X, Chang SX, Saurette DD (2011) Organic soils of Canada: Part 1. wetland Organic soils. Canadian Journal of Soil Science 91:807822. https://doi.org/10.4141/cjss10043

24. Loisel J, Yu Z, Beilman DW, et al (2014) A database and synthesis of northern peatland soil properties and Holocene carbon and nitrogen accumulation. The Holocene 24:1028-1042. https://doi.org/10.1177/0959683614538073

25. Mclachlan JS, Brubaker LB (1995) Local and regional vegetation change on the northeastern Olympic Peninsula during the Holocene. Canadian Journal of Botany 73:1618-1627.

26. Middleton BA (2020) Trends of litter decomposition and soil organic matter stocks across forested swamp environments of the southeastern US. PLoS ONE 15:23. https://doi.org/10.1371/journal.pone.0226998

27. Momsen JL (2007) A Mulit-Scale Approach to Reconstructing Landscape History in the Great Swamo National Wildlife Refuge, Morris County, New Jersey. Doctoral Dissertation, Dept of Ecology and Evolution, Rutgers University

28. Nahlik AM, Fennessy MS (2016) Carbon storage in US wetlands. Nature Communications 7:13835. https://doi.org/10.1038/ncomms13835

29. National Wetlands Working Group (1997) The Canadian Wetland Classification System, 2nd edn. the Wetlands Research Centre

30. Newby PE, Killoran P, Waldorf MR, et al (2000) 14,000 years of sediment, vegetation, and water-level changes at the Makepeace Cedar Swamp, southeastern Massachusetts. Quaternary Research 53:352-368. https://doi.org/10.1006/qres.1999.2120

31. Ott CA, Chimner RA (2016) Long-term peat accumulation in temperate forested peatlands (Thuja occidentalis swamps) in the Great Lakes region of North America. Mires and Peats 18:1-9. https://doi.org/10.19189/MaP.2015.0MB.182

32. Page SE, Rieley JO, Banks CJ (2011) Global and regional importance of the tropical peatland carbon pool. Global Change Biology 17:798-818. https://doi.org/10.1111/j.1365-2486.2010.02279.x

33. Peng Y, Schmidt IK, Zheng H, et al (2020) Tree species effects on topsoil carbon stock and concentration are mediated by tree species type, mycorrhizal association, and N-fixing ability at the global scale. Forest Ecology and Management 478:118510. https://doi.org/10.1016/j.foreco.2020.118510

34. Ramsey C (2009) Bayesian analysis of radiocarbon dates. Radiocarbon 51:337-360. https://doi.org/10.2458/azu_js_rc.51.3494.

35. Reimer PJ, Austin WEN, Bard E, et al (2020) The IntCal20 Northern Hemisphere Radiocarbon Age Calibration Curve (0-55 cal kBP). Radiocarbon 62:725757. https://doi.org/10.1017/RDC.2020.41

36. Santisteban JI, Mediavilla R, López-Pamo E, et al (2004) Loss on ignition: A qualitative or quantitative method for organic matter and carbonate mineral content in sediments? Journal of Paleolimnology 32:287-299. https://doi.org/10.1023/B:JOPL.0000042999.30131.5b

37. Saugeen Valley Conservation Authority (1979) Greenock Swamp Study.

38. Soil Classification Working Group (1998) The Canadian system of soil classification, 3rd edn. NRC Research Press, Ottawa

39. Trettin CC, Kolka RK, Marsh AS, et al (2020) Wetland and Hydric Soils. In: Pouyat R, Page-Dumroese D, Patel-Weynand T, Geiser L (eds) Forest and rangeland soils of the United States under changing conditions: A comprehensive science synthesis. Springer International Publishing, pp 99-126

40. Turton C, McAndrews J (2001) Wetland History Along the Escarpment: Two Swamps Near Crawford Lake. Leading Edge 2001

41. Verry ES (1997) Hydrological Processes of Natural, Northern Forested Wetlands. In: Trettin CC, Jurgensen MF, Grigal DF, et al (eds) Northern Forested Wetlands. CRC Press, pp 163-188

42. Watts WA (1979) Late Quaternary vegetation of central Appalachia and the New Jersey coastal plain. Ecological Monographs 49:427-469. https://doi.org/10.2307/1942471

43. Young DM, Baird AJ, Gallego-Sala A v., Loisel J (2021) A cautionary tale about using the apparent carbon accumulation rate (aCAR) obtained from peat cores. Scientific Reports 11:9547. https://doi.org/10.1038/s41598-021-88766-8

44. Zoltai SC, Siltanen RM, Johnson JD (2000) Canada A wetland data base for the western boreal, subarctic, and arctic regions of Canada Northern Forestry Centre - Information Report NOR-X-368. Information Report NOT-X-368E. 28 p, Edmonton, Alberta

\section{Figures}




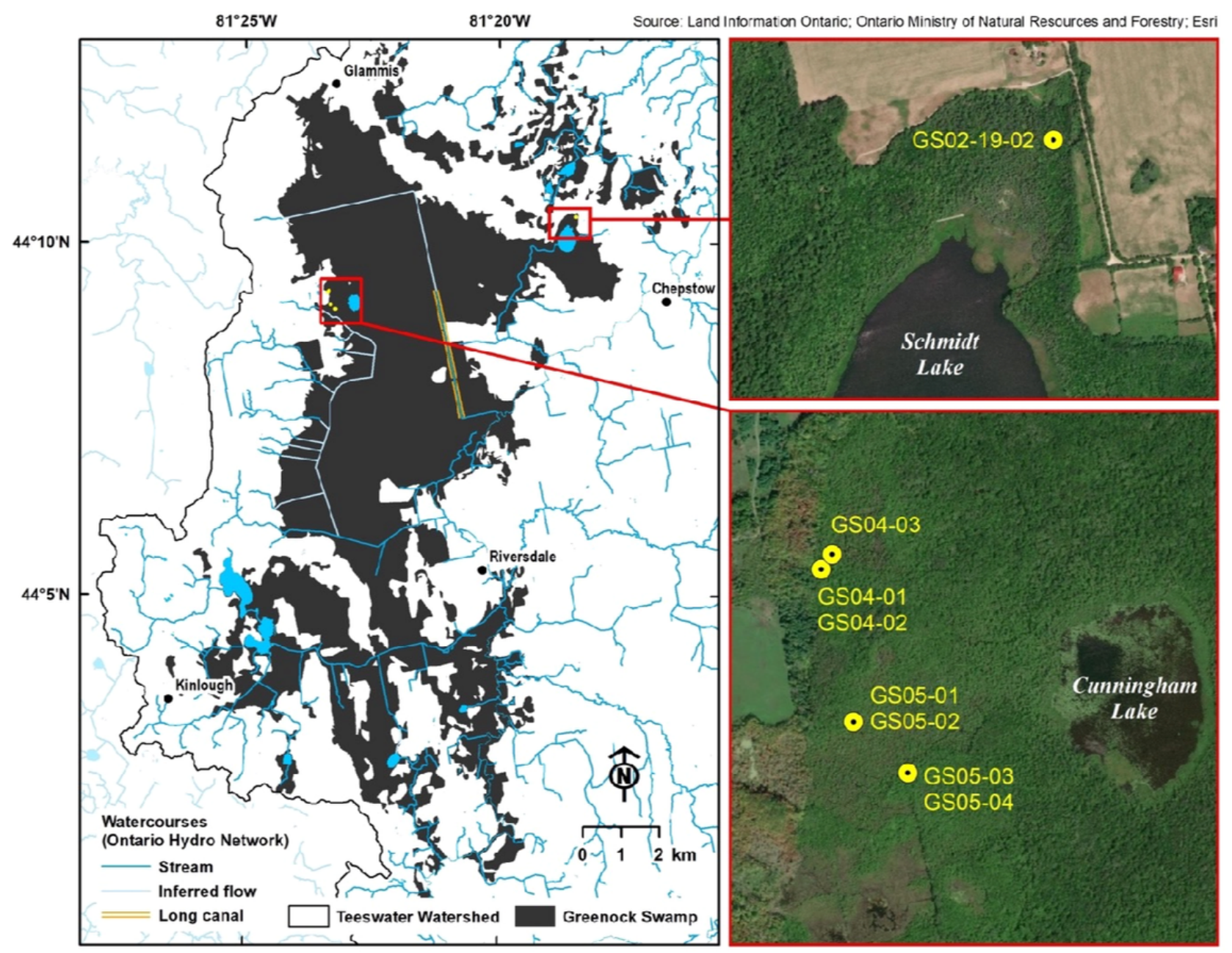

Figure 1

Greenock Swamp showing surface watercourses from Ontario Hydro Network (OHN); insets show GS02, GS04 and GS05 coring locations

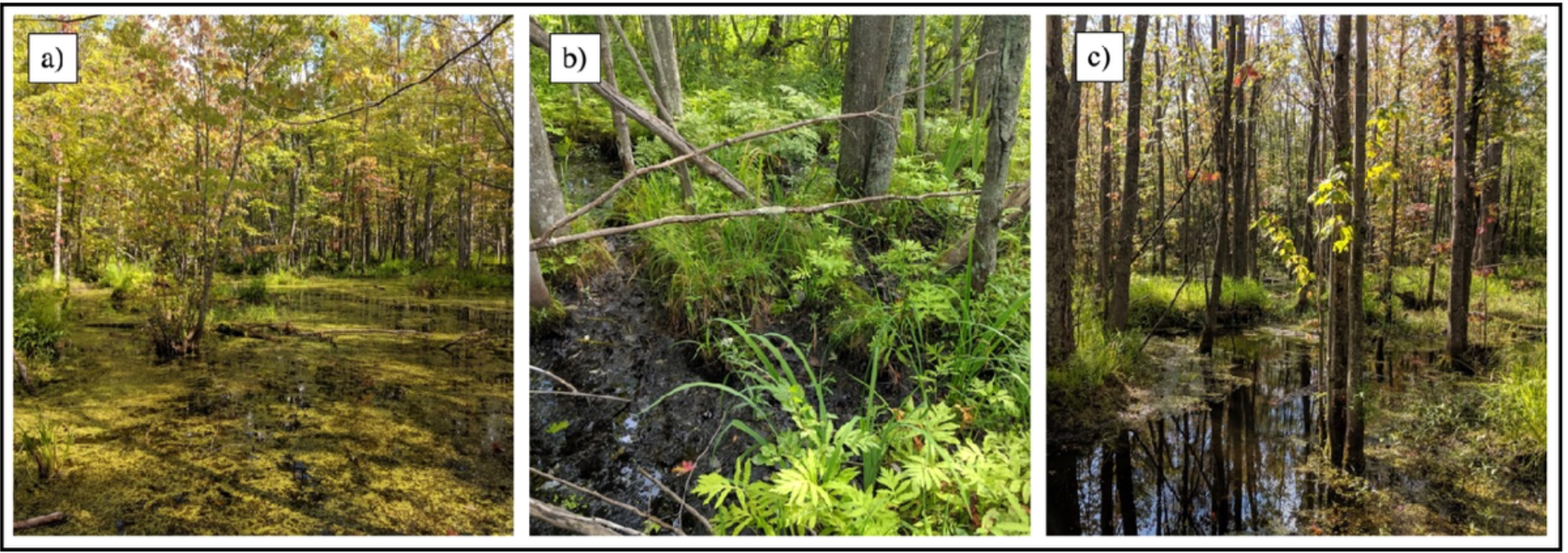

Figure 2

Photographs from Greenock Swamp. a) large pool at GS04 b) hummock and hollow at GS05 c) hummocks and pool at GS04. Photographs by Dean Hiler 

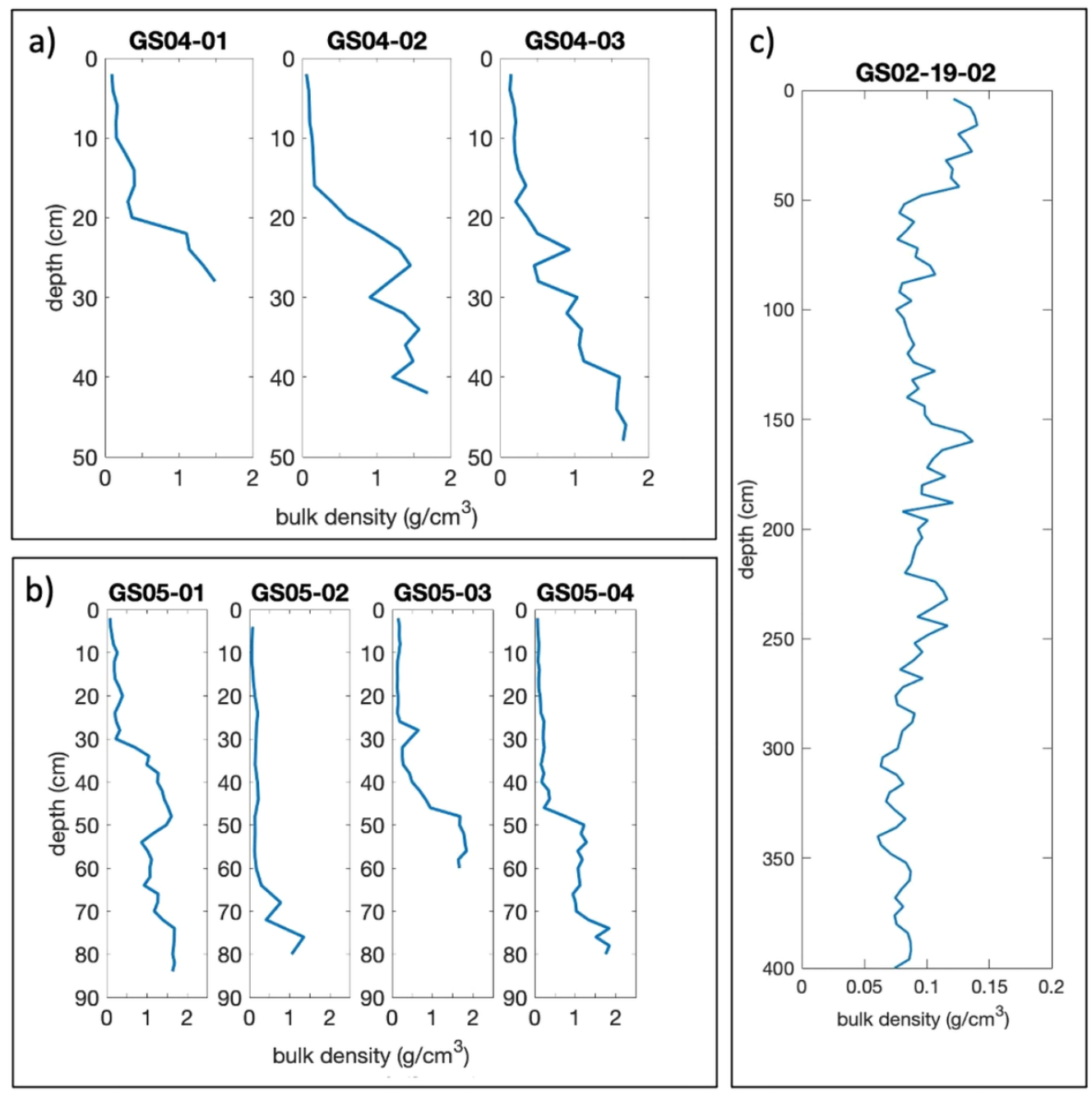

Figure 3

Bulk density profiles for broad-leaved sites a) GS04, b) GS05 and needle-leaved site c) GS02. Sampling resolution is every 2 cm for GSO4 and GS05 and every $4 \mathrm{~cm}$ for GS02 


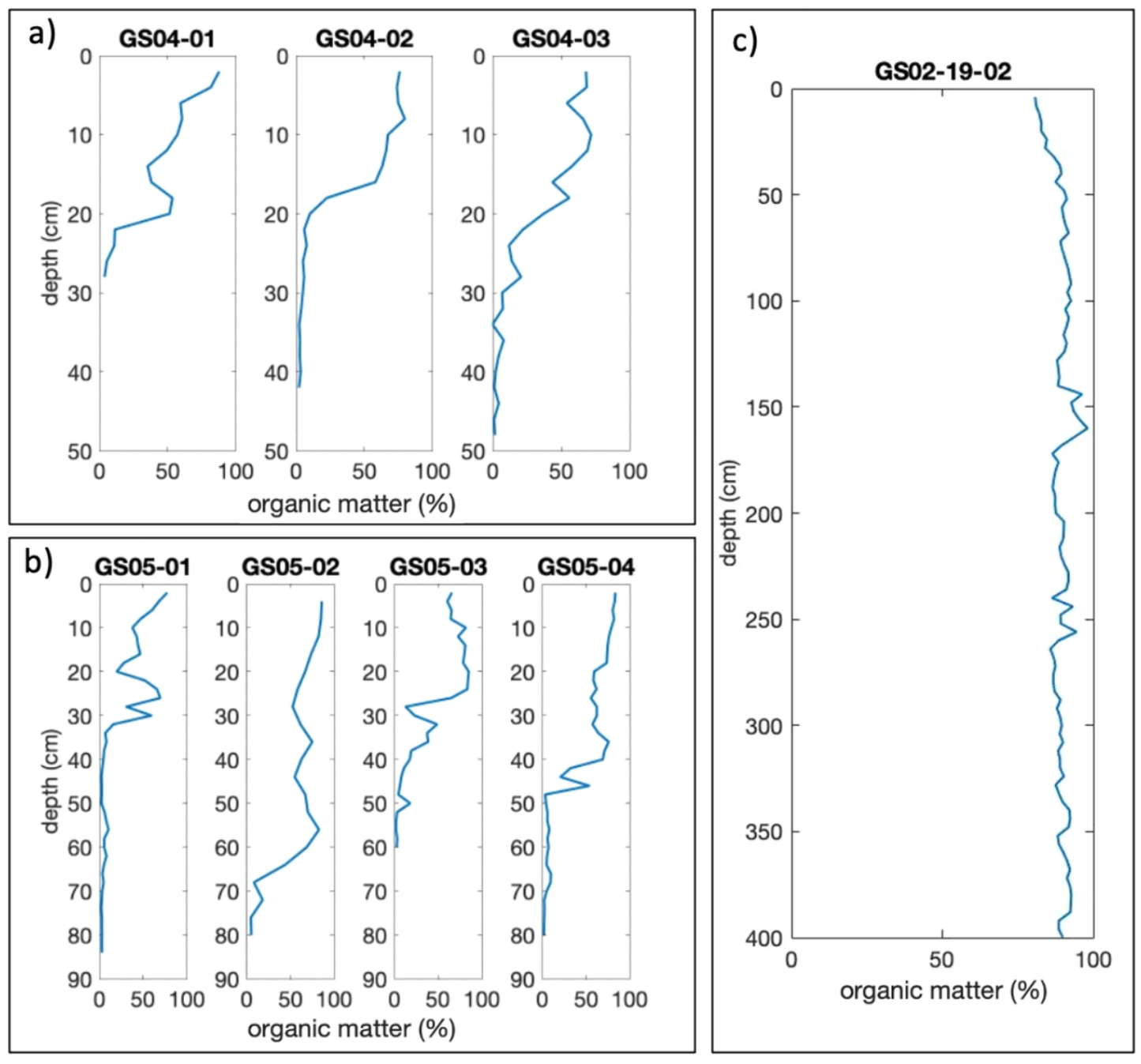

Figure 4

Organic matter as determined by LOI $550^{\circ} \mathrm{C}$ for broad-leaved sites a) GSO4, b) GSO5 and needle-leaved site c) GSO2. Sampling resolution is every $2 \mathrm{~cm}$ for GS04 and GS05 and every $4 \mathrm{~cm}$ for GS02 


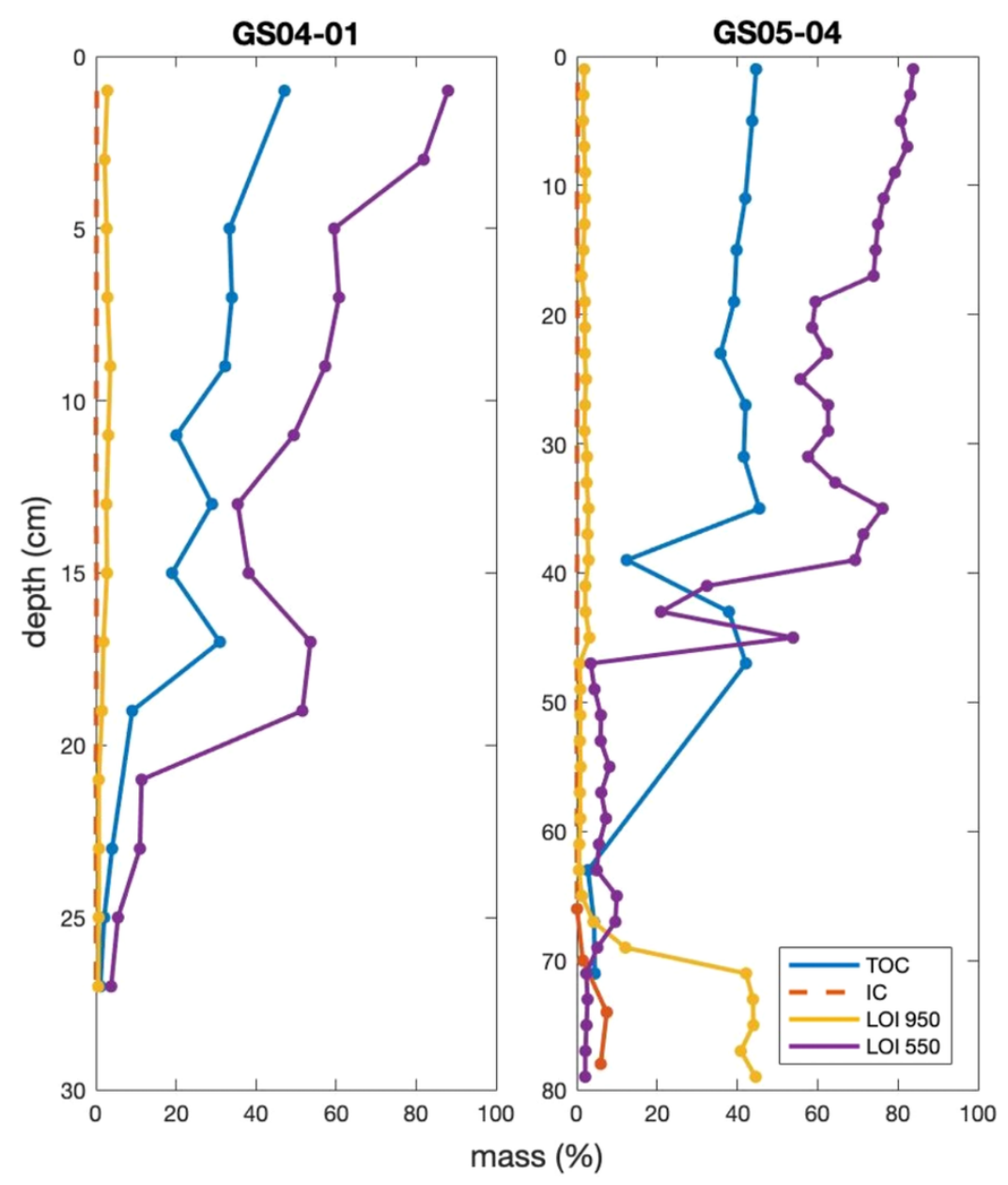

Figure 5

Results of carbon elemental analysis and loss-on-ignition for broad-leaved cores GS04-01 and GS05-04. Dashed lines indicate results below the detection limit of the carbon analyzer (carbon $<0.275 \%$ dry mass based on the sample mass used). Sampling resolution was every $2 \mathrm{~cm}$ except for GS05-04 TOC and IC, which was every $4 \mathrm{~cm}$ 


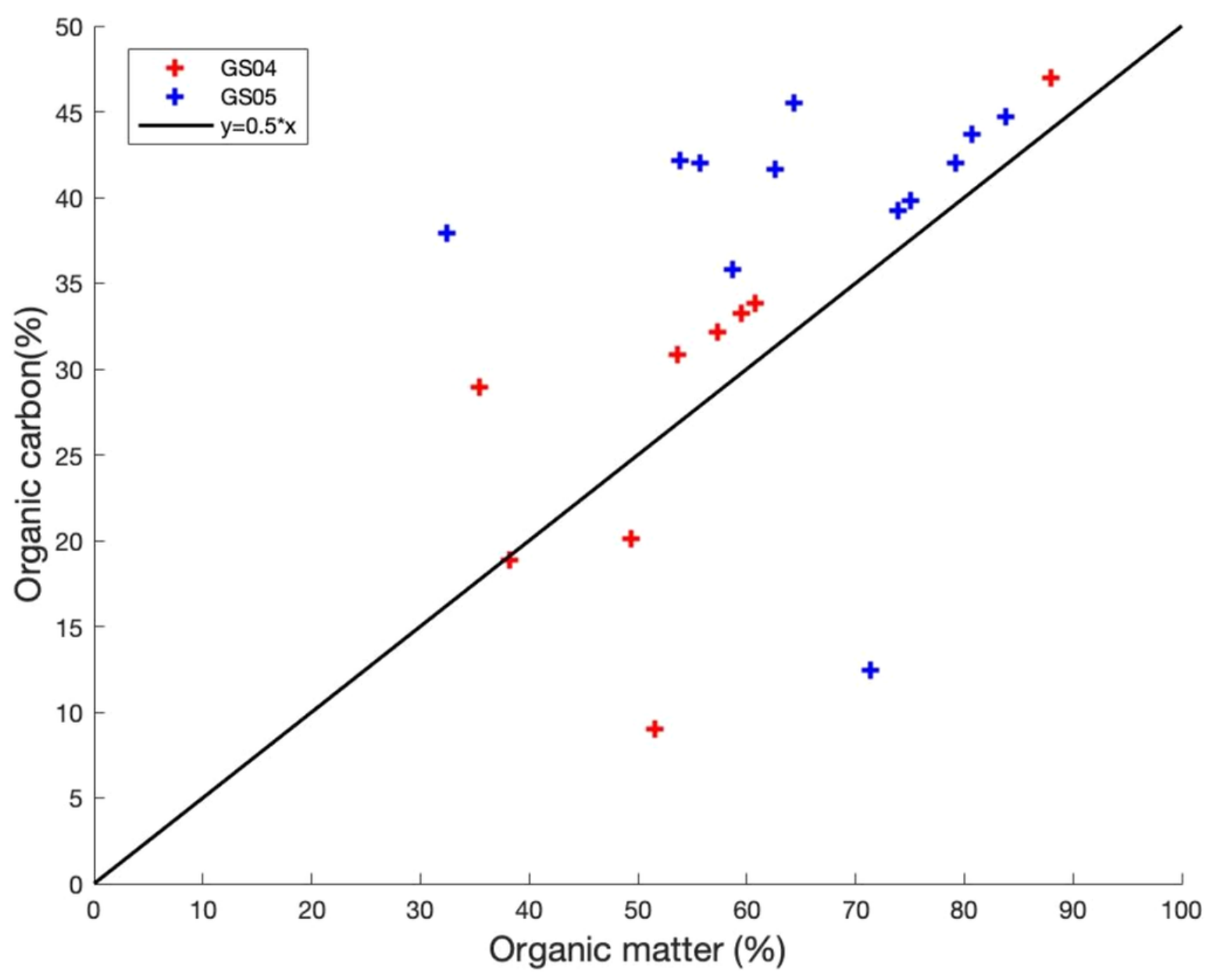

Figure 6

Organic matter (\%) estimated by LOI $550^{\circ} \mathrm{C}$ plotted with paired direct measurements of organic carbon (\%) for GS04-01 and GS05-04. Line shows the 2:1 organic matter to organic carbon ratio 